\title{
UMA ETNOGRAFIA DO BALÉ CLÁSSICO: ESCOLHAS, ANGÚSTIAS E VIVÊNCIAS INICIAIS
}

\author{
Fernanda Ferreira de Abreu $^{1}$
}

\section{Resumo}

Com base em minha experiência inicial de campo em escolas de dança de Niterói (RJ), proponho reflexões sobre a dimensão da subjetividade do pesquisador. Para tanto, estabeleço considerações acerca das motivações envolvidas nas escolhas do tema e do campo, tendo em vista minha posição de aluna de balé clássico anterior e simultânea a de pesquisadora. A ambiguidade acarretada é pensada sobretudo a partir das considerações de Devereux (1980) a respeito das "observações recíprocas" que se operam entre etnógrafo e nativo, com ênfase nas "contraobservações", normalmente relegadas pelos pesquisadores. Utilizando a noção de "ser afetado", proposta por Favret-Saada (2005), abordo ainda minha vivência no aprendizado corporal do balé clássico, passível de suscitar insights para a pesquisa.

Palavras-chave: etnografia; balé clássico; contraobservação; subjetividade.

\begin{abstract}
Based on my initial experience of field in dance schools of Niterói (RJ), I propose reflections on the dimension of the subjectivity of the researcher. To do so, I establish considerations about the motivations involved in the choices of subject and field, considering my position as classical ballet student and simultaneously researcher. The entailed ambiguity is thought considering the studies of Devereux (1980) about the "reciprocal observations" that operate between ethnographer and native, with emphasis on "counter-observations", usually relegated
\end{abstract}

\footnotetext{
${ }^{1}$ Doutora em Antropologia Social pelo Programa de Pós-graduação em Antropologia Social (PPGAS), Museu Nacional, Universidade Federal do Rio de Janeiro (UFRJ). E-mail: feabreu82@ hotmail.com
}

INTRATEXTOS, Rio de Janeiro, vol. 7, nº 1, 2015, p. 69-89. ISSN 2176-6789. 
by researchers. Using the notion of "to be affected" proposed by Favret-Saada (2005), I also approach my body experience in classical ballet, which can elicit insights for the research.

Keywords: ethnography; classical ballet; counter-observation; subjectivity. 


\section{Introdução}

Este artigo se insere no âmbito de minha pesquisa de doutorado sobre carreiras no ensino do balé clássico, iniciada em 2013. Tendo em vista que, de acordo com meu projeto original, eu tinha a intenção de dar continuidade à pesquisa da dança de salão realizada no mestrado, pretendo discutir as possíveis influências nessa mudança de tema, com destaque para o fato de eu ter praticado o balé clássico por aproximadamente dez anos, o que também teria interferido no trabalho de campo. Este foi concluído recentemente; porém, as reflexões realizadas no presente texto concentram-se nas experiências vivenciadas em meu primeiro ano de pesquisa, em relação às quais consegui estabelecer um distanciamento necessário para iniciar um processo de objetivação.

A ambiguidade acarretada por minha posição de aluna anterior e simultânea à de pesquisadora é pensada sobretudo a partir das considerações de Devereux (1980) sobre as "observações recíprocas" que se operam entre etnógrafo e nativo, com ênfase nas contraobservações. São desse autor estudos pioneiros a respeito de como gênero, classe social e profissão, entre outros marcadores sociais, podem condicionar os papéis que os nativos tendem a imputar aos pesquisadores; o que, por sua vez, permite o acesso a dados específicos a partir de determinado ponto vista. Entendo, assim, que estão imbricadas a obra produzida pelo pesquisador e sua trajetória para produzir essa obra, incluindo seus medos e hesitações. A intenção é, portanto, objetivar as subjetividades necessariamente envolvidas, tal como procuraram fazer as antropólogas Wulff (1998) e Hoppe (2000), que também já haviam sido alunas de balé clássico antes da experiência etnográfica.

Além disso, pretendo explorar como uma participação efetiva no campo e a vivência da subjetividade se constituem numa forma de construção de conhecimento. Adotando a noção de "ser afetado" proposta por Favret-Saada (2005), procuro descrever algumas percepções e sensações vivenciadas em meu corpo e por meio dele no processo de aprendizado do balé clássico.

\section{Tema e campo: escolhas}

Procuro pensar, inicialmente, nos motivos de minhas próprias investigações. No mestrado, tratei das práticas criativas femininas a partir do trabalho de campo em duas renomadas academias de dança de salão, nas quais me matriculei como aluna. Optei por não 
realizar nenhuma entrevista; os dados foram construídos por meio de minha participação em aulas e bailes, de observações e conversas informais. Por mais que soubessem que eu pesquisava a dança de salão, eu era vista como aluna. Até que ponto tinha, então, o direito de descrever o que acontecia? Eles se lembravam, de fato, que eram observados?

No doutorado, pensei inicialmente em pesquisar carreiras e trajetórias de professores de dança de salão. Atualmente, quatro anos depois da concepção de meu projeto preliminar, acredito que a opção por trabalhar com histórias de vida tenha sido também uma forma de evitar as aflições do mestrado. Como as entrevistas seriam necessárias, minha posição de pesquisadora ficaria mais evidente.

Com o falecimento repentino de meu orientador, comecei a pensar sobre a possibilidade de alterar o tema de pesquisa. Mantive a ideia de pesquisar carreiras e trajetórias de professores de dança, mas resolvi mudar para professoras de balé clássico ${ }^{2}$. Como já mencionado, eu faço aulas de balé há algum tempo. Do mesmo modo, já havia sido aluna de dança de salão em Niterói (RJ); porém, foi especificamente para a pesquisa de mestrado que me matriculei como aluna em duas academias de dança de salão situadas na cidade do Rio de Janeiro, por essas academias serem mais conhecidas e contarem com um maior número de alunos e professores. Contudo, analisando retrospectivamente, e após a leitura dos artigos de DaMatta e Velho, que abordam as possibilidades e desafios da observação do familiar, acredito que o fato dessas academias serem renomadas não tenha sido o único e nem o principal motivo da opção pela mudança para a realização da pesquisa.

Segundo DaMatta (1978), para se realizar uma pesquisa etnográfica, é preciso transformar o exótico em familiar e/ou o familiar em exótico. Essas transformações do objeto de pesquisa nunca são realizadas integralmente; porém, para se conseguir estudar um objeto próximo, seria preciso construir certo estranhamento. Já Velho (2008) estabelece uma distinção entre familiaridade e conhecimento, e ressalta que o conhecimento do que é familiar pode estar comprometido pela rotina, por estereótipos e preconceitos. Creio, assim, que entrar em duas novas academias tenha sido uma forma de me ajudar a estranhar o familiar ou a buscar um conhecimento menos comprometido pela familiaridade.

\footnotetext{
${ }^{2} \mathrm{Na}$ verdade, inicialmente, minha intenção era pesquisar não apenas as professoras, mas também os professores homens. No entanto, considerando que as mulheres são a grande maioria, e que, nos locais onde iniciei o campo, havia apenas mulheres, optei por focar a pesquisa nas professoras. Essa decisão ganhou força após eu começar a perceber os marcadores de diferenças que poderiam ser analisados dentro da categoria mulheres no contexto pesquisado, decorrentes de fatores como idade e características corporais, entre outros.
} 
Beaud e Weber (2007) também alertam para as dificuldades inerentes aos campos próximos; entretanto, sinalizam como uma imersão em determinado contexto pode ser aproveitada e convertida em objeto de pesquisa, desde que se tenha consciência das dificuldades envolvidas. De acordo com esses autores:

Tornar-se pesquisador quando se é de antemão participante (é o que chamamos de pesquisa por distanciamento) supõe uma tomada de distância pela qual não será possível apoiar-se sobre as próprias impressões de estranhamento. Em particular, tudo poderá parecer, de antemão, natural, evidente, automático, pois haverá explicação para tudo; ter-se-á a impressão de tudo saber. São inúmeros preconceitos dos quais será preciso livrar-se (p. 38-39, grifo dos autores).

De qualquer forma, o conhecimento será sempre uma construção; o objeto é necessariamente filtrado pelo ponto de vista do pesquisador. Cabe mencionar, ainda, que não é incomum a escolha de um objeto com o qual se tenha afinidade. Numa coletânea sobre arte, Becker, Faulkner e Kirshenblatt-Gimblett (2006) destacam que é relativamente habitual o estudo de artes com as quais os pesquisadores tinham afinidade antes de pensar em estudá-las, por vezes antes mesmo de se tornarem cientistas sociais. O conhecimento pessoal da arte estudada seria até uma ajuda para a pesquisa. Segundo esses autores, "conhecer a atividade e o mundo de pessoas, organizações e práticas em que elas ocorrem, além de ter familiaridade com seus produtos típicos, torna muito mais fácil a invenção de questões interessantes e pesquisáveis" (p. 15). ${ }^{3}$

O próprio Becker pesquisou músicos de jazz, sendo que ele era pianista de jazz e tocava em bares à noite. Conta este autor: "tudo o que eu tinha que fazer era manter um diário de campo sobre o que acontecia comigo. Quando chegava em casa, de manhã, fazia minhas anotações. E assim, em 1949, obtive o meu mestrado" (BECKER, 1990, p. 117). Ele confessa, inclusive, que não tinha sérias intenções de se tornar sociólogo; queria ser um grande pianista de jazz.

Por outro lado, mesmo em situações em que a formação em ciências sociais seja prioridade, a pesquisa etnográfica pode proporcionar um "agradável efeito colateral" (CARRIÇO, 2013, p. 12) ${ }^{4}$. Talvez a expectativa por esse efeito colateral tenha exercido influência em minha mudança de tema. Comecei a praticar o balé numa idade considerada

\footnotetext{
${ }^{3}$ Todas as traduções de trechos originalmente em língua estrangeira são de minha autoria.

${ }^{4}$ Nas reflexões referentes à sua pesquisa de mestrado sobre a qualificação profissional de padeiros, Carriço considera um bônus ter aprendido a fazer vários tipos de pães, no que ele estava sinceramente interessado; e dificilmente teria disponibilidade diária para realizar um curso de seis meses se não fosse pela pesquisa.
} 
tardia, aos 16 anos, e ainda precisei parar por alguns anos. A dança de salão foi uma alternativa para abrandar meu desejo de voltar para o balé. Havia turmas com aulas somente uma vez por semana e aos sábados. Apesar da dança de salão, acalentei a vontade de retornar ao balé, o que se tornou possível em 2009. Retomei as aulas, porém não na mesma academia onde havia começado, embora esta tenha sido minha primeira alternativa. Matriculei-me em outra academia de dança de Niterói, que freqüentei até o início de 2012, quando minha disponibilidade de horário motivou novamente a mudança, e voltei para minha primeira academia.

Ao perceber que as etnografias do balé clássico inicialmente encontradas, seja no Brasil ou em âmbito internacional (HOPPE, 2000; RUIZ, 2010; WULFF, 1998), tinham por objeto bailarinos profissionais ou em vias de profissionalização, pensei em pesquisar outra forma de se trabalhar com esta dança; forma esta normalmente invisibilizada, apesar de ser a principal alternativa dos que trabalham com o balé clássico: dar aula em academias que não têm como objetivo a formação de bailarinos profissionais, tal como fazem as professoras com as quais havia tido contato até então. Minha primeira ideia para a pesquisa de campo foi me matricular em renomadas academias da cidade do Rio de Janeiro, assim como havia feito no mestrado. Todavia, comecei a considerar se não seria profícuo partir desta vez de minha própria experiência como aluna de balé clássico de academias de dança de Niterói.

\section{O início da pesquisa de campo: angústias edificuldades}

Quando retornei à primeira academia de dança por mim frequentada como aluna, não falei nada sobre a pesquisa, pois nem mesmo havia oficializado a mudança de tema; e não dispunha de tempo em meu primeiro ano de doutorado para me dedicar ao trabalho de campo. Em 2013, passei para a turma de balé clássico mais adiantada desta academia, frequentada, sobretudo, por professoras. Durante um período, fui a única aluna desta turma que não era também professora. Apesar de ter menos tempo de experiência na dança e mais dificuldade para acompanhar as aulas, já iria para esta turma de qualquer forma, o que me possibilitaria progredir em meu aprendizado do balé; e foi também uma ótima oportunidade para a pesquisa.

Desse modo, algum tempo após minha inserção nessa turma adiantada, comecei a comentar que pretendia pesquisar as professoras de balé, uma vez que os poucos trabalhos existentes contemplavam, principalmente, bailarinas de grandes companhias; e que mais à 
frente gostaria de entrevistá-las. Dito isto, voltava a ser mais uma aluna. O que mudou de fato é que comecei a fazer anotações depois das aulas assim que chegava em casa; e fui acometida pela mesma angústia da pesquisa de mestrado: as ambiguidades (cf. WEBER, 2009, p. 53) provocadas por minha posição de aluna e pesquisadora. Mas nesse caso tinha o alento de que com as entrevistas meu papel de pesquisadora ganharia relevo. Ao mesmo tempo que ansiava por essas entrevistas, tinha medo de começar a solicitá-las; temia receber recusas.

Como, no segundo semestre, as professoras passam a ter bem menos tempo, pois se dedicam bastante à preparação do espetáculo de fim de ano, pensei que seria melhor deixar para investir nas entrevistas no primeiro semestre de 2014. Todavia, diante de minha ansiedade para de fato me reconhecer como pesquisadora, tracei o objetivo de realizar pelo menos uma entrevista ainda em 2013. Minha primeira opção foi $\operatorname{Ingrid}^{5}$ - uma das professoras da turma adiantada -, por ser a única professora da academia que não se envolve com o espetáculo de fim de ano, e especialmente devido à sua vasta experiência com o balé clássico ao longo de seus 80 anos de vida. Achei que ela gostaria de falar sobre sua carreira, pois, normalmente, antes do início das aulas, ela me contava (eu costumava ser a primeira a entrar em sala) situações vivenciadas ao longo de sua trajetória no balé. Isso era feito espontaneamente, sem nenhuma pergunta de minha parte. Somente demonstrava interesse em ouvi-la. Ao chegar em casa, anotava o que ela me contava. Mas, certamente, ela nem imaginava que eu estava fazendo isso, o que me deixava aflita.

Dessa forma, lembrei a Ingrid que fazia doutorado em antropologia e que gostaria de pesquisar trajetórias de professoras de balé clássico. Em seguida, perguntei se ela poderia me ajudar, concedendo-me uma entrevista sobre sua carreira. Sua resposta foi imediata: "pede para Marisa [a outra professora da turma]. Eu não gosto de entrevistas" - e complementou "tem uma matéria na revista com toda a minha trajetória". A referência foi feita a uma matéria de duas páginas que consta numa edição de uma revista especializada em dança, distribuída gratuitamente nas academias. Respondi que já havia lido essa matéria, e que gostaria de um pouco mais de detalhes; acrescentei em seguida que leria a matéria novamente, e indaguei se poderia lhe fazer algumas perguntas caso tivesse alguma dúvida. Ela concordou, mas depois disso não voltou a nos dar aula, visto que começamos a nos dedicar mais aos ensaios para o espetáculo de fim de ano.

\footnotetext{
${ }^{5}$ Todos os nomes foram trocados.
} 
Confesso que não esperava receber uma recusa. O que deve incomodá-la é a situação de entrevista, e por mais que eu tivesse frisado logo depois que seria mais uma conversa, ela manteve sua posição. Como não cabia pedir naquele momento uma entrevista para outra professora dessa academia, lembrei-me de que uma ex-colega de trabalho havia me dito que sua mãe, Lúcia, era professora de balé. Imediatamente, entrei em contato, e obtive uma resposta positiva. Mesmo assim, me preocupei. Será que ela só aceitou diante da insistência de sua filha? Fui bastante tensa para nosso primeiro encontro, marcado por minha (futura) interlocutora numa das academias de dança onde ela dá aula. Seria minha primeira entrevista, e embora tenha enfatizado a ansiedade para explicitar minha posição de pesquisadora, admito ser muito mais cômodo simplesmente participar e observar, devido a uma timidez que poderia me atrapalhar no estabelecimento de um primeiro contato e na situação de entrevista. ${ }^{6}$

Para minha surpresa e alegria, foi preciso perguntar muito pouco. Percebi que Lúcia podia falar por horas, e com prazer, sobre sua trajetória de vida e seu trabalho com o balé ao longo de mais de 30 anos. Foi bastante solícita e se mostrou muito disposta a contribuir para a pesquisa. Como eu já havia recebido uma recusa, procurei conduzir como uma conversa, e preferi não pedir para gravar nesta primeira vez, mas fiz algumas anotações na hora, após ter percebido que ela estava bem à vontade. Conversamos durante duas horas, e só não conversamos mais porque Lúcia tinha aulas para dar, e me convidou para assisti-las. Ela me passou os horários de todas as suas turmas, e disse para eu aparecer quando quisesse.

Saí desta primeira entrevista bastante animada; por um momento, todas as minhas angústias tinham se esvaído. Tal como expressou Favret-Saada (1980, p. 175), em relação a sua pesquisa da feitiçaria na França, "finalmente isso possibilitou me apresentar de um modo que me permitiu reconhecer a mim mesma". Cabe sinalizar que, no caso de Favret-Saada, não havia uma identificação anterior com a feitiçaria; seus interlocutores que a identificaram como uma desmanchadora de feitiços. E, para que conseguisse realizar a pesquisa, teve que decidir por assumir essa posição, fazendo de sua participação - do deixar-se "ser afetada" uma forma de construção de conhecimento. O alívio transcrito acima refere-se ao fato de que, após algum tempo, Favret-Saada pôde se identificar também como alguém que publicaria um livro; e obteve uma avaliação favorável da desmanchadora de feitiços de quem se tornou assistente, o que atribuiu ao fato de ela imaginar que encontraria segredos de seus

\footnotetext{
${ }^{6}$ De acordo com Beaud e Weber (2007, p. 22), "tudo não é, felizmente, questão de habilidade para se sobressair no campo; outras qualidades sociais, quase opostas, são mobilizáveis em situação de pesquisa, com destaque para a prudência, a circunspecção, a capacidade para escutar, para ficar retirado, para não julgar; a timidez pode ser, então, um trunfo".
} 
competidores no livro. De todo modo, parece ter sido reconfortante para a autora ser reconhecida também como pesquisadora. Já em meu caso, eu era aluna de balé muito antes da pesquisa. Dessa forma, minha preocupação era de que minha identidade de aluna ofuscasse a de pesquisadora, e que minhas interlocutoras esquecessem que eu estava também realizando uma pesquisa. Ainda que elas não tenham clareza das implicações que meu estudo pode vir a ter, na medida em que eu mesma não tenho total controle sobre seus desdobramentos e apropriações, a possibilidade de evidenciar a posição de pesquisadora me proporcionou certa tranquilidade. Com efeito, senti-me muito bem ao ser apresentada, nas aulas de Lúcia a que assisti - de turmas de criança e de adulto -, como pesquisadora, "uma pesquisadora que entende de balé".

Duas semanas depois, fiz minha primeira aula com Lúcia na turma de adulto, frequentada por alunas em diferentes níveis de aprendizado. Pensei que esta seria uma boa forma de manter contato e realizar uma pesquisa de longa duração. Ao pagar por suas aulas, poderia retribuir - ao menos um pouco - a ajuda recebida, ainda que ela estivesse dando mais para mim do que para as demais alunas. Além disso, senti que não poderia assistir às aulas continuamente, até mesmo por uma limitação de espaço físico. As salas desta academia são relativamente pequenas e me esforçava ao máximo para me encolher num canto. Desse modo, é sobre minha inserção como aluna e simultaneamente pesquisadora que irei me debruçar doravante.

\section{Contraobservações e desdobramentos}

[...] a característica fundamental da ciência do comportamento é a reciprocidade atual e potencial da observação entre observador e observado [...] o caráter unidirecional da observação é em grande parte uma ficção convencionada, forjada por dispositivos experimentais que minimizam a contraobservação (DEVEREUX, 1980, p. 48).

Tentarei evidenciar justamente essa contraobservação. Devido à dificuldade para acessar e objetivar a comunicação não-verbal, serão privilegiados comentários feitos por minhas interlocutoras a meu respeito.

Ao final de minha primeira aula com Lúcia, ela me perguntou: "você começou o balé com quantos anos mesmo?" Respondi que aos 16 , conforme já lhe havia dito; e ela comentou com um tom enfático: "se você tivesse começado mais cedo, teria sido bailarina". Fiquei feliz 
com o elogio recebido, mas, ao mesmo tempo, um pouco triste e reflexiva: por que não investi no aprendizado do balé quando ainda era criança? Será que gostaria de ter sido uma bailarina?

Lembrei-me do que a professora Marisa me falou há muitos anos: "você tem uma BMW. Agora, é só aprender a dirigir como uma BMW". O que eu supostamente tenho é o que ela chama de "talento físico"7 para o balé: capacidade de rotação para fora (endehors) das pernas e dos pés, peito do pé proeminente - "pé bonito" ou "pé forte", como dizem - e alongamento. Esses estão, inclusive, entre os principais atributos físicos avaliados na prova de ingresso para a Escola Estadual de Dança Maria Olenewa (EEDMO) ${ }^{8}$, pioneira na profissionalização de bailarinos clássicos no Brasil e referência até hoje. Uma bailarina também precisa ser magra para transmitir leveza e ser sustentada pelo bailarino; porém, de uma forma geral, é considerado mais fácil emagrecer do que adquirir os outros atributos físicos mencionados.

Hoppe (2000) relata a dificuldade que teve para começar a frequentar as dependências da EEDMO para a realização de sua pesquisa, devido à experiência que havia tido com o balé clássico. Aos 11 anos, ela se inscreveu para a prova de ingresso - bastante concorrida - desta escola; porém, um pouco antes de sua realização, ficou inapetente, e a falta de alimentos atrelada ao esforço físico provocou um quadro de estafa. Seus pais decidiram, portanto, que ela não iria realizar a prova. Na dissertação de mestrado, redigida 15 anos após este episódio, ela reconhece que foi a melhor decisão, mas na ocasião ficou muito contrariada, pois tinha a intenção de se tornar bailarina. Em suas palavras: "induzida por meus pais, reavaliei as privações necessárias à profissionalização, como, por exemplo, de alimentos, descanso e convívio social, e desisti da carreira de bailarina" (p. 34).

Devido a essas exigências, penso que não gostaria de ter sido uma bailarina profissional. Mas e quanto a ser uma professora de balé? Numa aula com Marisa, ela ressaltava, como faz habitualmente, a importância de evitar "vícios" e demonstrar corretamente para as alunas. "Uma boa demonstração é tudo". E no final de seu discurso, acrescentou que isso só não se aplicava a mim, que não era professora. "Pelo menos por enquanto. Nunca se sabe o dia de amanhã" - disse Marisa. Admito que, por um momento, considerei essa possibilidade. Questionei, posteriormente, se, em meu processo de definição

\footnotetext{
${ }^{7}$ Escapa ao escopo deste trabalho a problematização dessa categoria e a explicitação de suas condições sociais e culturais. Cabe, porém, sinalizar que a expressão "talento físico" é utilizada por minhas interlocutoras em referência aos atributos corporais que consideram inatos.

${ }^{8}$ Localizada no Centro da cidade do Rio de Janeiro, a EEDMO pertence à Fundação Theatro Municipal do Rio de Janeiro.
} 
do objeto, estariam em jogo identificações - conscientes ou inconscientes - como as que operaram, por exemplo, na pesquisa feita por Powdermaker (1966) em Hollywood, na qual esta autora privilegiou os atores em detrimento dos roteiristas. Vinte anos após a realização da pesquisa, ela diz achar que foi ameaçada inconscientemente pelos roteiristas, pois nutria por eles uma inveja inconsciente, ou seja, queria se tornar um deles embora não admitisse isso. Em seus termos: "o problema, no entanto, não estava em meu envolvimento, mas no fato de eu não estar consciente de sua real natureza. Se eu estivesse consciente, talvez tivesse sido capaz de objetivar a situação e estudá-la com maior distanciamento" (p. 229).

Só devo conseguir fazer uma reflexão como essa posteriormente. Será que no meu caso, diferentemente da situação narrada por Powdermaker, eu escolhi estudar as professoras de balé porque gostaria de ser uma delas? A pesquisa talvez ofereça a possibilidade de eu me convencer de que esta não teria sido uma boa opção, na medida em que tenho acesso, especialmente ao longo das entrevistas, às dificuldades enfrentadas pelas professoras.

Por ora, penso ser mais importante me indagar acerca dos aspectosque minha posição de aluna permite conhecer. As colocações de Wulff podem contribuir para a reflexão. Essa autora, uma antropóloga sueca, fez uma etnografia de companhias de balé renomadas mundialmente, e no prólogo de seu livro conta que aos dois anos de idade já dançava quando ouvia música, e que, em função disso, seus pais a levaram para aulas de balé clássico. Foram 15 anos de prática intensa, até que, aos 17 anos, ela teve que parar devido a uma lesão na coluna vertebral. Contudo, Wulff $(1998$, p. 1) ressalta: "meu corpo ainda se lembra do que se sente ao dançar. Aprender a dançar e dançar são experiências que nunca vão embora completamente. A sensação é ativada, por exemplo, quando eu ouço uma música que eu costumava dançar”. São sinalizadas, assim, duas vantagens para a pesquisa propiciadas por sua experiência na dança:

Primeiro, uma carreira na dança é difícil. Momentos de triunfo, como ovações e aplausos, são muito curtos. Mas como eu costumava dançar, eu sei algo sobre a dor - e a paixão - de dançar que me propiciou o respeito e a confiança dos dançarinos. Por ter crescido no mundo do balé, eu possuo o tipo de capital social que estrutura o idioma no teatro, tanto no palco quanto nos bastidores (WULFF, 1998, p. 5).

Com efeito, também sinto que consigo compreender melhor o "mundo do balé", e especialmente as sensações e vivências corporais - retomadas no tópico seguinte - de minhas interlocutoras, em função de minha experiência, apesar de eu não ser nem nunca ter sido professora, bem como Wulff sinaliza que nunca chegou a ser uma bailarina profissional. Para 
ilustrar alguns aspectos que me foram permitidos conhecer devido à minha posição de aluna, trago duas situações.

Antes do início da aula da turma adiantada, quando me encontrava em sala apenas com a professora Ingrid, aproveitei para pedir para ela ver se eu estava conseguindo executar bem um movimento em relação ao qual havia sido corrigida na aula anterior. Ela disse que eu havia assimilado a correção, e complementou: "quando eu era aluna, também era assim. Sempre procurava me lembrar do que a professora falava". Comentou, em seguida, que havia sido a aluna preferida de uma renomada professora russa, e me contou algumas peculiaridades das aulas com essa professora. Desse modo, a partir de minha atitude, ela lembrou e verbalizou algumas de suas próprias experiências como aluna de balé.

Em outra aula, a professora Marisa explicitou a relação, frequentemente comentada em academias de dança, entre "talento físico" e esforço, com o objetivo de incentivar uma aluna que não é considerada endehors: "quem é talentosa já larga na frente na corrida. Mas não adianta ser talentosa sem se esforçar. Há vários casos na academia de pessoas que são talentosas fisicamente e não se esforçam, e de pessoas não tão talentosas que se esforçam mais e acabam se destacando mais". Sou considerada, por essa professora, esforçada, além de portadora de "talento físico", conforme já mencionado. Embora eu supostamente tenha essas duas características consideradas importantes, ela acha que eu nãoas utilizo plenamente, pois fico tensa nos espetáculos e nas próprias aulas. Essa tensão também compromete o aspecto artístico, fundamental à dança. $\mathrm{O}$ contraponto são aquelas alunas que gostam de plateia, que têm "marra" ou "talento artístico". As que supostamente têm esse "talento artístico", mas não são dotadas de"talento físico", costumam dizer para as que têm a combinação oposta (meu caso): "o que você tem - talento físico - eu não vou ter nunca, mas você pode ter o que eu tenho". Certa vez em que isso foi dito, Marisa ponderou: "não é bem assim, essa 'marra' é da essência da pessoa; é muito difícil mudar quem não nasceu com isso". Dessa forma, por meio das observações feitas a meu respeito, tenho acesso a opiniões de minhas interlocutoras referentes aos atributos considerados importantes para uma bailarina clássica; e isso me ajuda a construir questões sobre as próprias professoras pesquisadas.

Como elas se movem entre esses parâmetros, ou seja, entre talentos considerados inatos ou "dados por Deus" e os atributos que podem ser adquiridos ou aprendidos mediante esforço e disciplina? Como essas características são atribuídas, quais as combinações possíveis, e de que maneira influenciam a escolha pela carreira de professora em detrimento da de bailarina? Já ouvi Marisa frisar inúmeras vezes que o endehors e o peito de pé que ela 
adquiriu foi através de muito trabalho e esforço; e apesar disso, ela reconhece que tem muito menos desses atributos do que alunas suas que simplesmente "nasceram endehors e com peito de pé”. Por outro lado, ela sempre gostou de se exibir e de se apresentar em público, ou seja, teria "nascido com talento artístico". Já a professora Lúcia se orgulha de seu pé com curvatura bastante acentuada, que ela fez questão de me mostrar na entrevista; contudo, diz ter tido que trabalhar muito o endehors. Além disso, conta ter começado o balé um pouco "tarde", por volta de dez anos de idade, e entrou para a EEDMO com mais de vinte anos. "Não dava para competir com as meninas que estavam lá desde crianças" - ela se justifica.

Penso ser importante ressaltar que as contraobservações que procurei objetivar apontando seus possíveis desdobramentos - se inserem num contexto de experiência partilhada (cf. DEVEREUX, 1980) ou no que Weber (2009) chamou de "estar com", considerando que a não-participação num contexto de pesquisa etnográfica seria uma ficção. De acordo com essa autora, "não há uma exterioridade absoluta do pesquisador: este último torna-se um nativo, isto é, um sujeito a ser observado, na medida em que um lugar lhe foi atribuído num espaço social local. Tal lugar não é uma invenção, já existe anteriormente, ao menos como potencialidade" (p. 32).

Portanto, seria comum a ambivalência de se ocupar uma ou mais posições além da de pesquisador(a), o que não necessariamente implica deslizes éticos. Abu-Lughod (1999) de certa forma resolveu esse conflito ao explicitar como a socialização pode construir autenticidade. Ela foi sincera ao participar; realmente se sentiu como "filha" numa comunidade beduína. Ainda que não seja beduína, ela é descendente de árabes; e seu pai biológico a acompanhou em parte da pesquisa de campo, tendo em vista as implicações sociais que ela teria, por ser uma mulher jovem desacompanhada. Como "filha", Abu-Lughod sentiu-se também responsável pela reputação de seus interlocutores. Ao atentar para seus códigos de conduta, passou a partilhar de experiências e sentimentos.

A diferença, no meu caso, é que eu já era aluna de balé muito antes da pesquisa. De qualquer modo, sinto-me parte das academias de dança onde faço aula, e tenho um interesse sincero em aprender balé. Nas aulas e nos espetáculos de fim de ano, procuro fazer o melhor que posso para corresponder ao que se espera de uma aluna de balé de uma turma adiantada de uma academia de dança de Niterói. Mais do que partilhar uma experiência, ser aluna é também uma via para me deixar "ser afetada" (cf. FAVRET-SAADA, 2005) por experiências, vivências e aprendizados que afetam minhas interlocutoras. 


\section{"Ser afetada": corpo e aprendizado}

É preciso esclarecer que Favret-Saada (2005) enfatiza que o dispositivo de "ser afetado" não é observação participante e muito menos empatia; trata-se de efetivamente participar, de vivenciar a subjetividade e até mesmo arriscar se perder. E o que isso acarreta em termos de conhecimento? Segundo a autora, "o próprio fato de que aceito ocupar esse lugar e ser afetada por ele abre uma comunicação específica com os nativos: uma comunicação sempre involuntária e desprovida de intencionalidade, e que pode ser verbal ou não" (p. 159).

Em minha pesquisa, o aspecto não-verbal da comunicação é especialmente relevante; mas, ao mesmo tempo, é muito difícil traduzir essa vivência corporal em palavras, como já ressaltaram inúmeros pesquisadores. Wacquant (2002, p. 90), por exemplo, que se tornou um aprendiz de boxe para a realização de sua pesquisa, sinaliza numa nota de rodapé: "É com razão que ela [a extrema sensualidade da iniciação pugilística] escapa ao leitor, que só pode entrar no universo pugilístico pela intermediação da escrita. Ora, a simples passagem para a escrita transforma irremediavelmente a experiência que se trata de comunicar".

Há uma literatura fenomenológica no âmbito da antropologia que procura dar conta das experiências e sensações corporais, e ressalta a importância de se utilizar a própria experiência do pesquisador como dado primário da pesquisa, tal como é feito na coletânea organizada por Jackson (1996). No Brasil, também podem ser encontradas etnografias de inspiração fenomenológica, como a de Bizerril (2007), que pesquisa uma linhagem taoísta. Em sua tentativa de narrar a prática de artes marciais, este autor frisa, entretanto, que "descrever o que se vive com o corpo, no corpo, é um desafio aos limites da linguagem" (p. 132), e assim "um texto etnográfico só pode capturar um pequeno lampejo" (p. 165).

A própria Favret-Saada (2005, p. 160) destaca como um dos traços distintivos de sua proposta: "no momento em que somos mais afetados, não podemos narrar a experiência; no momento em que a narramos não podemos compreendê-la. O tempo de análise virá mais tarde". Farei, desse modo, uma primeira tentativa de narrar uma experiência vivenciada em campo. Antes, devo lembrar que a aula (ou melhor, uma pequena parte dela) a ser relatada se insere num tempo mais amplo; trata-se de uma sensibilidade prática aprendida ao longo de anos por meio de vivências compartilhadas. 
Por estar frequentando com regularidade uma turma adiantada, sinto que tenho progredido no aprendizado do balé, e talvez o fato de eu ter começado a fazer fouettés ${ }^{9}$ ilustre isso. A sensação de ter conseguido - ainda que poucos, e com muitos aspectos a melhorar - é incrível; trata-se da melhor sensação de superação que já senti em minha vida. Ela pode ser associada à hipótese de Wulff (2008, p. 525) para a permanência do balé clássico até nossos dias, apesar de demandar grande esforço, disciplina e sacrifício: “com a habilidade de mover e manipular seus corpos de modos bem mais elaborados, os bailarinos podem sentir um prazer profundo".

A professora Marisa costuma deixar os fouettés para o final da aula, incentivando cada aluna com palavras de correção e estímulo, e também com sua energia; sinto que ela realmente fica na torcida para que possamos dar o nosso melhor. Antes de começarmos os fouettés, meus dedos do pé já estão bastante doloridos e latejando. Quando dá tempo, tiro um pouco as sapatilhas e movimento meus dedos, para que possam respirar, ainda que brevemente. De qualquer forma, meus pés doem. Meu corpo já está extremamente cansado; e por ele escorre um suor que amarga minha boca e faz meus olhos arderem, que mancha meu collante e flutua no ar, juntando-se aos dos demais corpos e inebriando o ambiente. O medo de executar um movimento extremamente difícil me paralisa; porém, o desafio e o êxtase da superação me impulsionam. Uma música dinâmica tem início e inspira o movimento ditando um ritmo constante que deve ser seguido. Duas filas, duas alunas por vez; quando a menina à minha frente termina, devo me posicionar e prestar atenção para não perder a música. Sigo a contagem, e procuro me lembrar de tudo em que devo pensar: levar a perna livre bem ao lado, levantar o queixo, alongar bem a perna de base, não deixar o calcanhar desabar no chão, puxar o corpo para cima, sempre para cima! A professora grita correções. Procuro segui-las, e ao mesmo tempo conto cada fouetté, com a contribuição do compasso da música. Já foram quatro, mas ainda não estou conseguindo levar a perna ao lado, também devo esticar mais a ponta do pé. "Seu pé está frouxo; não abandona o pé” - exclama a professora. "Agora sim!” ela elogia e me estimula. Perceber a presença da menina ao lado, mais experiente, também me incita a continuar.“Fecha o braço direito mais rápido!” A dor é esquecida e fenece a cada giro; procuro me concentrar nas correções. Devo girar a cabeça com agilidade, mantendo um ponto fixo no espelho, para conferir dinâmica ao movimento. Mais uma cabeça! Foram dez fouettés!

\footnotetext{
${ }^{9}$ Sequência de piruetas executada pela bailarina, que usa a perna que não está na base (ou seja, que não está no chão) como impulso, sem tocá-la no chão até seu final. Trata-se de um dos passos mais difíceis, senão o mais difícil, e é especialmente aplaudido em balés de repertório como O Lago dos Cisnes e Don Quixote, nos quais a primeira bailarina normalmente executa 32 fouettés.
} 
O máximo que consegui! Não estou tonta, mas meu pé parou de responder, não tenho mais força para subir na ponta, e assim termino. Por ora. A menina ao lado continua. Invade-me uma sensação maravilhosa. Embriagante. Quero mais. A professora, contudo, alerta: "é normal não conseguirmos repetir imediatamente, pois nos cobramos muito para que saia igual, e isso acaba atrapalhando". Ainda há muito a melhorar. A emoção de ter conseguido é incrível. A aula já está terminando. Melhor parar e ir para casa com a sensação de dever cumprido, pelo menos até a próxima tentativa. Meu corpo está à beira da exaustão, o suor pinga e marca o chão; é assim que gosto de sair das aulas, realmente trabalhei e dei o melhor de $\operatorname{mim} .^{10}$

Tiro as sapatilhas, e sinto um novo prazer ao libertar meus dedos. Meus pés terão o descanso merecido. Dor, prazer, cansaço, êxtase, exaustão, embriaguez, medo, superação. De acordo com Lutz e Abu-Lughod (1990), as emoções são fenômenos incorporados, situados no corpo, o que não significa que sejam "naturais". Conforme a concepção contextualista proposta por essas autoras, as emoções são ações que constituem as próprias relações sociais e instauram realidades que só existem em contexto; e não simplesmente expressam ou revelam sentimentos que estariam ocultos. As emoções narradas precisam, assim, ser entendidas tendo em vista o contexto de uma aula da turma mais adiantada de uma academia de Niterói. Em ensaios e espetáculos, por exemplo, as realidades seriam outras.

Marisa ressalta que a sala de aula é o espaço para ousarmos e errarmos. Afinal, ninguém pagou ingresso e não tem nenhum concorrente assistindo. Segundo ela, a pior coisa que tem para um professor é o aluno que não tenta. Errar em aula não tem nenhum problema. Há sempre algo para corrigir e melhorar, por maior que seja o tempo de prática do balé. Uma correção frequente para mim em relação aos fouettés é a "levada da perna ao lado", pois tenho a "tendência de cortar o movimento da perna" antes que ela chegue efetivamente ao lado, o que prejudica a coordenação do giro. Na tentativa de me ajudar a aplicar essa correção, a professora me recomendou ao final de uma aula: "quando você for dormir, procure se visualizar fazendo o movimento correto, levando bem a perna ao lado". Comentei que seria mais uma forma de o movimento entrar em minha memória corporal. Ela concordou, e disse chamar isso de automatismo.

\footnotetext{
${ }^{10}$ Este relato aproxima-se do de Wacquant (2002, p. 88) em relação aos treinos de boxe: “[...] vem o prazer de sentir o corpo adelgaçar-se, 'fazer-se' pouco a pouco pela disciplina que lhe é imposta. Além do sentimento de cansaço e de plenitude corporal amiúde vivaz que ele proporciona, o treino é, nele mesmo, sua própria recompensa, quando o lutador consegue dominar um gesto difícil, que oferece a sensação nova de ter redobrado sua potência, ou quando obtém uma vitória sobre si mesmo".
} 
É destacado por Alarcón (2009, p. 6) - filósofa e pesquisadora da dança a partir de uma perspectiva fenomenológica - que a memória corporal consiste "numa recordação de uma dinâmica corporal sentida". A autora menciona ainda que em cada movimento sentimos a nós mesmos, e que isso pode ser chamado de "consciência corporal". De fato, o "sentir"associado a uma autopercepção e à constituição de uma "consciência corporal" - é bastante enfatizado pelas professoras de balé. Sobre os fouettés, por exemplo, Marisa me perguntou se eu sentia que estava levando a perna ao lado. Respondi negativamente, e ela disse que era bom que eu não estivesse sentindo, pois ficaria mais fácil para eu me corrigir.

Cabe também mencionar que as professoras normalmente dão dicas a partir do que sentem que funciona melhor em seus próprios corpos; porém, pedem para testarmos e vermos o que dá certo em nossos corpos. A esse respeito, aproprio-me das reflexões de Carriço (2013, p. 17) acerca de sua experiência como pesquisador e simultaneamente aprendiz de padeiro: "não posso supor que sentiram da mesma forma que eu, sequer que o processo tenha sido o mesmo. Posso, no entanto, partir de algum lugar. Como aluno afetado por todo um processo de sensibilização, posso levar a sério e explorar essa própria condição". É isso que tenho me proposto a fazer: deixar-me "ser afetada" de forma a estabelecer uma comunicação com minhas interlocutoras que não seja necessariamente verbal; e levar a sério a produção de determinadas sensibilidades e o quanto meu corpo é transformado nesse processo.

Procurei seguir o conselho de visualizar-me antes de dormir executando o "movimento correto", o que não foi difícil, pois já tinha o hábito de repassar mentalmente coreografias ou sequências de passos ao me deitar. O problema é que às vezes também tenho a sensação de cair no palco. E o palco é o espaço para acertarmos, diferentemente da sala de aula. Tenho apenas cinco minutos para mostrar o que aprendi ao longo de todo o ano; a música não vai voltar para que eu tente mais uma vez. O medo de errar me trava e faz com que minhas pernas subam menos, com que eu permaneça menos tempo nas pontas dos pés. Esses detalhes normalmente não são percebidos pelo público dos espetáculos das academias, que, em grande medida, não tem um conhecimento técnico do balé, por ser composto por familiares e amigos das alunas. Mas e se eu cair? Por isso, é preferível me conter. Por outro lado, a sensação de que dei o meu melhor no espetáculo é indescritível. Em comparação às aulas, essa sim é uma experiência de êxtase. Pena que a senti poucas vezes. A tensão parece me dominar.

Não sei dizer o quanto a recomendação de minha professora - referente à visualização do movimento para torná-lo automático - funcionou, porquanto começamos logo depois a ensaiar uma coreografia e não pratiquei mais os fouettés. Ainda estou longe de ser 
considerada apta para executá-los no palco, mas não pretendo desistir. Marisa incentiva suas alunas dizendo que quando conseguirem executar os fouettés de forma correta não desaprenderão mais. É como andar de bicicleta. O fato de que "o jeito de andar de bicicleta, uma vez aprendido, nunca é perdido indica que as habilidades sensoriais e motoras necessárias deixam uma impressão anatômica indelével, ainda que apenas na normalmente invisível arquitetura do cérebro" (INGOLD, 2000, p. 376). Novamente a questão da memória corporal, da memória que uma vez inscrita no corpo gera movimentos automáticos.

Sinto que haveria muito mais a ser dito, mas sou detida por alguns obstáculos. Além do escopo deste trabalho, que é uma primeira tentativa de pensar minhas escolhas e vivências no campo, devo mencionar que continuo a frequentar aulas de balé clássico; e não sei se posso considerar que a pesquisa de campo está de fato finalizada. Como última consideração, talvez possa aventar a possibilidade futura de revisar e comparar os dados aqui construídos com aqueles que serão produzidos posteriormente à medida que a pesquisa gere desdobramentos que ainda não posso precisar.

Recebido em Janeiro de 2016 Aceito em Fevereiro de 2016 


\section{REFERÊNCIAS BIBLIOGRÁFICAS}

ABU-LUGHOD, Lila. Veiled sentiments:honor and poetry in a bedouinsociety. Berkeley: UniversityofCalifornia Press, 1999.

ALARCÓN, Mónica. "La inversión de la memoria corporal endanza". A Parte Rei. Revista de Filosofía,n. 66, p. 1-7, nov. 2009.

BEAUD, Stéphane; WEBER, Florence. Guia para a pesquisa de campo: produzir e analisar dados etnográficos. Petrópolis: Vozes, 2007.

BECKER, Howard.“Uma entrevista com Howard S. Becker”.Estudos Históricos, v. 3, n.5. p. 114-136, 1990.

BECKER, Howard; FAULKNER, Robert; KIRSHENBLATT-GIMBLETT, Barbara."Editors' Introduction". In: (Eds.). Art from start to finish. Chicago: University of Chicago Press, 2006. p. 1-20.

BIZERRIL, José. O Retorno à raiz:uma linhagem taoísta no Brasil. São Paulo: Attar, 2007.

CARRIÇO, Antônio. "Discutindo metodologia: contribuições de uma pesquisa etnográfica sobre qualificação profissional”. In: XIII Encontro Nacional da Associação Brasileira de Estudos do Trabalho (ABET).Anais de trabalhos.

DAMATTA, Roberto. "O ofício de etnólogo, ou como ter anthropological blues". In: NUNES, Edson de Oliveira (Org.). A aventura sociológica. Objetividade, paixão, improviso e método na pesquisa social.Rio de Janeiro: Zahar, 1978. p. 23-35.

DEVEREUX, Georges.De l'angoisse à la methode dans les sciences du comportement. Paris: Aubier, 1980. 
FAVRET-SAADA, Jeanne. "Ser afetado". Cadernos de Campo (USP),n. 13, p. 155-161, 2005.

FAVRET-SAADA.Deadly words: witchcraft in the Bocage. Cambridge: Cambridge University Press, 1980.

HOPPE, Sigrid. Produção corporal da mulher que dança.2000.Dissertação (Mestrado em Antropologia) - Programa de Pós-Graduação em Antropologia, UFF, Niterói - RJ.

INGOLD, Tim.The perception of the environment: essays on livelihood, dwelling and skill. London: Routledge, 2000.

JACKSON, Michael(Ed.).Things as they are: new directions in phenomenological anthropology.Bloomington: Indiana University Press, 1996.

LUTZ, Catherine; ABU-LUGHOD, Lila."Introduction: emotion, discourse and the politics of everyday life". In: (Eds.). Language and the politics of emotion. Cambridge: Cambridge University Press, 1990. p. 1-23.

POWDERMAKER, Hortence. Stranger and friend. New York: Norton, 1966.

RUIZ, Sandra. Partituras delcuerpo: etnografía sobre bailarines de puntas y media puntasenlaciudad de Córdoba. 2010.Dissertação (Mestrado em Antropologia) - FFyH/UNC, Córdoba - Argentina.

VELHO, Gilberto. “Observando o familiar". In: Individualismo e cultura: notas para uma antropologia da sociedade contemporânea. 8.ed. Rio de Janeiro: Zahar, 2008.p. 122-134.

WACQUANT, Loïc. Corpo e alma: notas etnográficas de um aprendiz de boxe. Rio de Janeiro: Relume-Dumará, 2002.

WEBER, Florence. Trabalho fora do trabalho: uma etnografia das percepções. Rio de Janeiro: Garamond, 2009. 
WULFF, Helena. "Etherealexpression: paradoxesof ballet as a global physicalculture". Ethnography,v. 9, n. 4, p. 518-535, 2008.

WULFF, Helena. Ballet across borders: career and culture in the world of dancers.Oxford: Berg, 1998. 